\title{
The Effect of Financial Leverage, Company Sizes, Basic Earning Power and Activity Ratio to Earning Per Share
}

\author{
Berlian Karlina ${ }^{1}$, Muhamad Rifki Ramadhan ${ }^{2 *}$ \\ ${ }^{1,2}$ Faculty of Economics and Business, Universitas Budi Luhur, Jakarta 12260, Indonesia
}

\begin{abstract}
A B S T RACT
The purpose of this research is showed to know the effect of Financial Leverage, Firm Size, Basic Earning Power and Activity Ratio to Earning Per Share on manufactured companies automotive and components sub-sector that listed on Indonesian Stock Exchange period 2013-2017. Sampling is done by purposive sampling method. The population in this research were 13 companies and the sample used were 12 manufacturing companies of automotive and components sub sector that listed on Indonesian Stock Exchange period 2013-2017. The method used in this research is hypothesis testing method. The analytical tool used is multiple linear regression analysis tested by using Program SPSS version 20 and Microsoft Excel 2016. The data used is secondary data in the form of complete financial statements during research period. The result of this research shows that Financial Leverage, Firm Size and Basic Earning Power have an effect to Earning Per Share. While Activity Ratio has no effect to Earning Per Share.
\end{abstract}

ARTICLE INFO

Article History:

Received : 30-08-2019

Revised : 22-11-2019

Accepted : 24-11-2019

Published : 28-10-2019

\section{Keywords:}

Financial Leverage,

Firm Size,

Basic Earning Power,

Activity Ratio and Earning Per Share

*Corresponding Author E-mail: rifkiramadhan182@gmail.com

Copyright (c) 2019 Authors. This is an open access article distributed under the Creative Commons Attribution License, which permits unrestricted use, distribution, and reproduction in any medium, provided the original work is properly cited.

\section{INTRODUCTION}

The automotive and component industries in Indonesia have developed into an important pillar in manufacturing sector in the country because many world-famous car companies have the manufacturing factories or even increasing their production capacity in Indonesia, a country with economy the largest in Southeast Asia as well as the countries with the largest population in Southeast Asia and the fourth position largest population in the world. This is interesting world companies, especially automotive and component companies to open factories in Indonesia. This is used as an opportunity for the company to develop its business.

Investors who will invest their funds will certainly do a certain analysis to assess whether the funds he will invest provide a favorable dividend at this time and in the future or not, an investor is not only attracted by the company's performance but 
also by the value of Earning Per Share produced by the company. Potential investors are attracted by large Earning Per Share and continue to increase every year, because Earning Per Share is one indicator of the success of a company. According to Salim (2014) Earning Per Share or earnings per share is the profit earned by each share. The higher value of Earning Per Share shows that the company is in a healthy condition and will be one of the factors that attract investors to invest their funds in the company.

There are many ways to develop business growth undertaken by automotive industries is to maximize funding sources. Sources of funding can be sought from internal funds and external funds, if internal funds are limited the company can look for alternatives additional from external funds by lending and selling shares in the capital market with attractive investor's attention to buying shares circulated by the company. One indicator that makes investors interested to invest are the level of Earning Per Share of a company. Variables that can affect Earning Per Share refers to some previous research, which is Financial Leverage this research is calculated by Debt To Equity Ratio, Company Size, Basic Earning Power and Which activity ratio in this study is proxied by Total Assets Turnover.

\section{LITERATURE REVIEW}

\section{Financial Leverage}

According to Rodoni and Ali (2014) the Financial Leverage ratio or also called the debt ratio is a toolin considering the possibility of company negligence on debt contracts. Financial Ratio The leverage used is Debt To Equity Ratio. According to Harjadi (2015) the ratio of debt to Equity (Debt To Equity Ratio = DER) is a ratio that measures the extent of debt can be fulfilled by own capital. The formula is as follows:

$$
\text { Debt to Equity Ratio }=\frac{\text { Total Debt }}{\text { Equity }}
$$

\section{Company Size}

According to Jogiyanto (2017) the asset size variable is measured as the logarithm of the total assets. According to Rodoni and Ali (2014) the formula for calculating Company Size is as the following:

$$
\text { Company Size }=\text { Ln (Total Asset })
$$

\section{Basic Earning Power}

According to Brigham and Houston (2010) the ratio of basic ability to generate profits (Basic Earning Power-BEP is calculated by dividing the amount of profit before interest and taxes (EBIT) with total assets. The formula is as follows:

$$
\text { Basic Earning Power }=\frac{\text { EBIT }}{\text { Total Assets }}
$$

\section{Activity Ratio}

According to Rodoni and Ali (2014) the activity ratio shows how effective the company is use the resources (assets or capital) it has. The ratio of activities used in This research is Total Assets Turnover, a ratio that measures the efficiency of asset use to generate sales. The formula is as follows:

$$
\text { Total Assets Turnover }=\frac{\text { Sales }}{\text { Total Assets }}
$$

\section{Earning Per Share}

According to Harjadi (2015) Earning Per Share (EPS) is a ratio that shows the share of earnings of for each share. So EPS illustrates the profitability of the company illustrated in each share. EPS can be calculated by the formula:

$$
\text { Earning Per Share }=\frac{\text { Net Profit }}{\text { Number of Shares Outstanding }}
$$

\section{Research Framework}

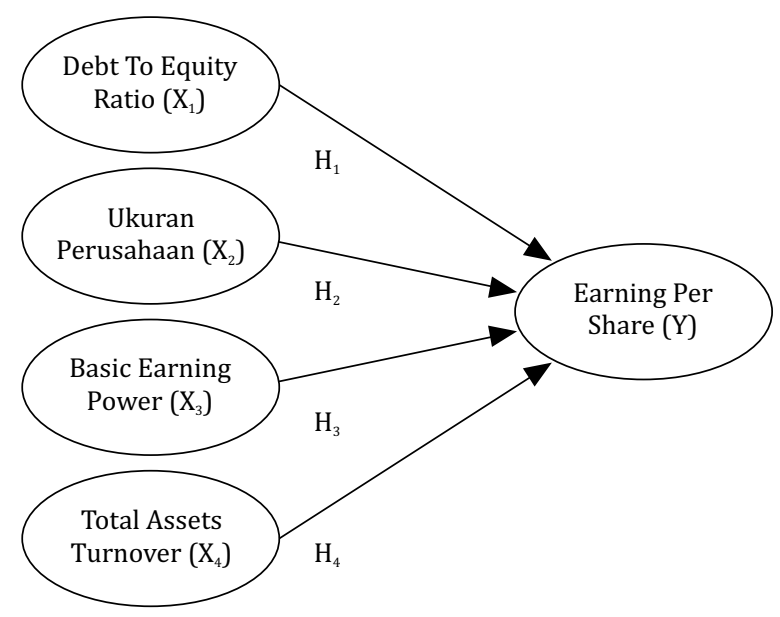

Figure 1. Research Framework 


\section{RESEARCH METHODS}

\section{Research Population}

In this study the population used was 13 automotive subsector manufacturing companies and components listed on the Indonesia Stock Exchange for the period 2013-2017.

\section{Research Samples}

Purposive Sampling sampling technique used in this study. Company automotive sub-sector manufacturing and components during the 20132017 research period streaks are listed on the Indonesia Stock Exchange and in that period always publishes reports Complete financial, audited, widely publicized. Amounts that meet the criteria There are 12 of 13 companies.

\section{Research model}

Hypothesis testing is a research model used in this study, which is related with the influence of Financial Leverage, Company Size, Basic Earning Power, and Activity Ratio against Earning Per Share is to use multiple linear regression. The multiple linear regression equation in this study is as follows:

$$
Y=a+b 1 X 1+b 2 X 2+b 3 X 3+b 4 X 4+e
$$

$\mathrm{Y}=$ Dependent variable predicted

$\mathrm{a}=$ constant

$\mathrm{b}=$ Regression coefficient

$\mathrm{X} 1, \mathrm{X} 2, \mathrm{X} 3, \mathrm{X} 4=$ Value of independent variables $\mathrm{e}=$ error

\section{Multiple Linear Regression Analysis}

The regression coefficient of the Earning Per Share variable is influenced by the variable Debt To Equity Ratio (Financial Leverage), Company Size and Basic Earning Power so that the regression equation is obtained as follows:

LN_EPS = -0,286 - 0,734 LN_DER + 0,232 LN_UP + 0,928 LN_BEP

Can be interpreted based on the multiple linear regression equation above, which is as follows:

1. Constant -0,286, this means that if the Debt To Equity Ratio (LN_DER), Company Size (LN_UP) and Basic Earning Power (LN_BEP) are 0 , the Earning Per Share is -0.286 .

2. Debt To Equity Ratio (LN_DER) regression coefficient of -0.734 , which means that if Debt To Equity Ratio increases by 1 unit then Company Size (LN_UP) and Basic Earning Power (LN_BEP) are fixed, then Earning Per Share will decrease in the amount of 0.734 units.

Negative coefficient means that there is a negative influence between the independent variable and the dependent variable, the higher the Debt To Equity Ratio, the lower the Earning Per Share, and vice versa.

3. Firm size variable regression coefficient (LN_UP) of 0.232, which means if the Company Size has increased by 1 unit then Debt To Equity Ratio (LN_DER) and Basic Earning Power (LN_BEP) are fixed, then Earning Per Share will increase by 0.232 units. Positive coefficient means that there is a positive influence between the independent variable and the dependent variable, the higher the Company Size, the higher the Earning Per Share, and vice versa.

4. The regression coefficient of the variable Basic Earning Power (LN_BEP) is 0.928, which means that if Basic Earning Power has increased by 1 unit then Company Size (LN_UP) and Debt To Equity Ratio (LN_DER) has a fixed value, then Earning Per Share will increase by 0.928 units. Positive coefficient means that there is a positive influence between the independent variable and the dependent variable, the higher the Basic Earning Power, the higher the Earning Per Share, and vice versa.

\section{RESULTS AND DISCUSSION}

Effect of Financial Leverage on Earning Per Share According to Rodoni and Ali (2014) the ratio of Financial Leverage or also called the debt ratio is a tool in considering the possibility of company default on debt contracts. The Financial Leverage Ratio used is Debt To Equity Ratio. In this study Debt To Equity Ratio has a negative effect on Earning Per Share, it can be explained that if Debt To Equity Ratio increases, Earning Per Share will decrease. The results of this study are consistent 
with Anwar's (2017) study which states that Debt To Equity Ratio has a significant effect on Earning Per Share.

Effect of Company Size on Earning Per Share According to Sartono (2016) large companies that have Well-Estabilshed will be easier to obtain capital in the capital market compared to small companies. Because the ease of access means that large companies have greater flexibility as well. In the study of company size has a positive effect on earnings per share, it can be explained that if the size of the company increases, the earning per share will increase. The results of this study are in line with the study of Mudjijah (2015) which states that company size has a positive and significant effect on earnings per share.

Effect of Basic Earning Power on Earning Per Share According to Brigham and Houston, the result of the translation of Ali Akbar Yulianto (2010) the ratio of the basic ability to generate profits (Basic Earning Power-BEP) is calculated by dividing total profit before interest and tax (EBIT) with total assets. In this study Basic Earning Power has a positive effect on Earning Per Share, it can be explained that if Basic Earning Power increases, Earning per Share will increase. The results of this study are in line with research Zamri, Purwati, and Sudjono (2016) which states that Basic Earning Power has a positive and significant effect on Earning Per Share.

Effect of Activity Ratio on Earning Per Share According to Rodoni and Ali (2014) the activity ratio shows how effectively a company uses its resources (assets or capital). Use of company resources to generate sales. The activity ratio used is Total Assets Turnover, which is a ratio that measures the efficiency of using assets to generate sales.

In this study, Total Asset Turnover has no effect on Earning Per Share, this shows that the high and low of Total Asset Turnover does not affect Earning Per Share. The results of this study are consistent with Kusuma's (2014) study which states that Total Asset Turnover has no effect on earnings per share.

\section{CONCLUSION}

Based on these results, the conclusion is that Financial Leverage, Company Size and Basic Earning Power affect Earning Per Share while the Activity Ratio has no effect on Earning Per Share in the automotive subsector and component manufacturing companies listed on the Indonesia Stock Exchange for the period 2013-2017.

The results of this study can be implicated for companies and investors, namely: for companies, it is expected to pay attention to factors that influence the ups and downs of Earning Per Share, such as Financial Leverage, Company Size and Basic Earning Power. But it also needs to pay attention to factors that do not affect Earning Per Share such as Activity Ratio because the management of assets by the company is less than optimal so the Activity Ratio does not affect Earning Per Share. Investors are expected to be considered by investors to make appropriate and profitable investments by looking at ratios that can affect earnings per share.

\section{RE F EREN CES}

Agnes, Sawir. 2014. Analisis Kinerja Keuangan Perusahaan dan Perencanaan Keuangan Perusahaan. Jakarta: Gramedia Pustaka Utama.

Brigham, Eugene F. dan Joel F. Houston. 2010. Dasar-Dasar Manajemen Keuangan. Edisi 11. Buku 1. Alih Bahasa Ali Akbar Yulianto. Jakarta: Salemba Empat.

Fahmi, Irham. 2017. Analisis Laporan Keuangan. Cetakan ke-6. Bandung: Alfabeta. 
Ghazali, Imam. 2016. Aplikasi Analisis Multivariete Dengan Program IBM SPSS 23. Edisi 8. Cetakan ke-8. Semarang: Badan Penerbit Universitas Diponegoro.

Harjadi, S. 2015. Pasar Modal Indonesia Pengantar dan Analisis. Edisi Revisi. Bogor: iN MEDIA.

Hery. 2016. Analisis Laporan Keuangan. Jakarta: PT Grasindo.

Horne, James C Van dan John M. Wachowicz, Jr. 2014. Prinsip-Prinsip Manajemen Keuangan. Edisi 13.

Buku1. Alih Bahasa Qurratul, ain Mubarakah. Jakarta: Salemba Empat.

Jogiyanto, Hartono. 2017. Teori Portofolio dan Analisis Investasi. Edisi 11. Yogyakarta: BPFE

Joko, Salim. 2014. Cara Gampang Bermain Saham. Jakarta: Visi Media.

Kasmir. 2015. Analisis Laporan Keuangan. Edisi ke-1, Cetakan ke-8. Jakarta: Rajawali Pers.

Kusuma, Septian Yudha. 2014. Pengaruh Net Sales, Total Asset Turnover, Suku Bunga Kredit dan Kurs USD Terhadap Earning Per Share (EPS) Pada Perusahaan Otomotif dan Komponen yang Tercatat Di Bursa Efek Indonesia (BEI). Jurnal Manajemen \& Bisnis Indonesia. Vol. 3, No. 2, ISSN : 2089- 6875.

Mubarok, Alvian Alvin, Palti MT. Sitorus dan Anisah Firli. 2017. Pengaruh Financial Leverage terhadap Earning Per Share Pada Perusahaan Subsektor Telekomunikasi Yang Terdaftar Di BEI Periode Tahun 2010-2014. E-Proceeding of Management. Vol. 4, No. 1, ISSN : 2355-9357.

Mudjijah, S. 2015. Analisis Pengaruh Faktor-Faktor Internal Perusahaan Terhadap Earning Per Share. Jurnal EKonomi dan Manajemen. Vol. 4, No. 2, ISSN : 2252-6226.

Nurcholidah, Lilik. 2017. Analisis Pengaruh Financial Leverage (Debt Ratio), Net Profit Margin (NPM), Return On Assets (ROA) dan Return On Equity (ROE) Terhadap Earning Per Share Perusahaan Tekstil di Jawa Timur. Jurnal Penelitian Ilmu Manajemen. Vol. 2, No. 3, ISSN : 2502-3780.

Nurjanah, Sri Devi. 2016. Pengaruh Cash Position, Firm Size, Debt To Equity Ratio, Dan Return On Equity Terhadap Dividen Payout Ratio Terhadap Dividen Payout Ratio Pada Perusahaan Otomotif Dan Komponen Periode 2011-2015. Universitas Budi Luhur. Jakarta.

Priyatno, Duwi. 2013. Analisis Korelasi, Regresi dan Multivariate dengan SPSS. Cetakan Pertama. Yogyakarta: Gava Media.

Putranto, Agung Tri. 2018. Analisis Laporan Keuangan Untuk Menilai Kinerja Keuangan PT Mayora Indah Tbk Tangerang. Jurnal Sekuritas (Saham, Ekonomi Keuangan dan Investasi). Vol. 1, No. 3, ISSN (Online) : 2581-2777,ISSN (Print) : 2581-2696.

Rodoni, Ahmad dan Herni Ali. 2014. Manajemen Keuangan Modern. Edisi Asli. Jakarta: Mitra Wacana Media.

Rudangga, I Gusti Ngurah Gede dan Gede Merta Sudiarta. 2016. Pengaruh Ukuran Perusahaan, Leverage dan Profitabilitas Terhadap Nilai Perusahaan. E-Jurnal Manajemen Unud. Vol.5 No.7, ISSN: 23028912.

Santoso, Singgih. 2015. Menguasai Statistik Parametrik Konsep dan Aplikasi Dengan SPSS. Jakarta: PT Elex Media Komputindo.

Sartono, Agus. 2016. Manajemen Keuangan Teori Dan Aplikasi. Edisi ke-4. Cetakan ke-8. Yogyakarta : BPFE

Shinta, Kumala dan Herry Laksito. 2014. Pengaruh Kinerja Keuangan, Ukuran Perusahaan dan Arus Kas Operasi Terhadap Earning Per Share. Diponegoro Journal of Accounting. Vol. 3, No. 2, ISSN : 23373806. Semarang.

Sugiyono. 2017. Metode Peneltian Kuantitatif, Kualitatif, dan R\&D. Cetakan ke-25. Bandung: CV Alfabeta. Sujarweni, V. Wiratna. 2015. SPSS Untuk Penelitian. Yogyakarta: Pustaka Baru Press.

Syaiful, Anwar. 2017. Analisis Pengaruh Debt To Equity Ratio, Return On Assets, Current Ratio, Total Assets Turnover, dan Price Earning Ratio terhadap Earning Per Share. Simki-Economic. Vol. 1, No. 3, ISSN : BBBB-BBBB. Kediri.

Syamsuddin, Lukman. 2019. Manajemen Keuangan Perusahaan. Cetakan ke-11. Jakarta : RajaGrafindo Persada.

Uno, Mohamad Barlianta, Hendra Tawas dan Paulina Van Rate. 2014. Analisis Kinerja Keuangan, Ukuran Perusahaan, Arus Kas Operasi pengaruhnya Terhadap Earning Per Share. Jurnal EMBA. Vol. 2, No. 3, ISSN : 2303-1174. 
Berlian Karlina, Muhamad Riki Ramadhan / The Effect of Financial Leverage, Company Sizes, Basic Earning Power and Activity Ratio to Earning Per Share / 136 - 141

Zamri, Nurul Amaliah, Atiek Sri Purwati dan Sudjono. 2016. Pengaruh Rasio Profitabilitas dan Leverage Terhadap Earning Per Share (EPS) (Studi Empiris Pada Perusahaan Manufaktur yang Terdaftar di Bursa Efek Indonesia Tahun 2012-2015). Jurnal Ekonomi dan Bisnis Islam. Vol. 1, No. 2, ISSN : 24609404. 